\title{
Ocene/Reviews
}

\section{Notes on Slovene and Slavic Etymology}

The notes which follow find aspects of F. Bezlaj’s Etimološki slovar slovenskega jezika to criticize. I hope this will not be taken adversely. On the other side of the balance we have an enormous debt of gratitude which we owe Bezlaj for the fact that he has given us the first major step in the production of a modern etymological inventory of the Slovene language and the scholarly exploration of the history of its lexicon. The critical nature of these notes is meant to point rather to the directions we may and must follow in the future, in my modest opinion; and which we may, thanks to the enormous aid that Bezlaj's work offers us, whereby we stand on his shoulders. Moreover, we must always remember that in the difficult days when Bezlaj was compiling much of his work there were many publications that were simply not available across borders in the world.

The principal themes of the following notes are the first-order contribution of Slovene evidence to the comparison and history of the Slavic languages; their place in and contribution to the history of the Indo-European languages; the importance of Indo-European evidence to the solution of Slavic problems; the clarity and illumination that comes from an insistence on the absolute regularity, in principle, of linguistic change; and the cumulative nature of scholarship.

\section{1 krma I, II, and Krma III}

F. Bezlaj, Etimološki slovar slovenskega jezika II K-O, 1982, 95-6, agrees with received opinion in tracing krma I 'pabulum' and its clear Slavic cognates to $\mathrm{IE} *(s) k e r$ - 'rezati' with the suffixal formation *-mo-, $-m \bar{a}$. This attribution must be roughly correct, but the specification offered for the aggregate derivation is imprecise to a degree that today we must exert ourselves to avoid.

Czech krmě is of course not precisely *-mā. Serbo-Croatian kr̀me -ta 'svinja', collect. kr̈mād is yet another formation. The semantics here also requires fuller specification. One might think of pork as the preferred food or meat in Northern Europe, as I have argued in the Festschrift for Marija Gimbutas (1987) and in Zeitschrift für Celtische Philologie 41, 1986, 257-8. But the prevalence of expressions with krmiti (also in Czech) for 'fatten' (esp. for slaughter) and for feeding pigs leads one to suspect that the formation of kr̈me is based on feeding the pig, as in krmáča and in $k r m e k$, rather than in the pig as potential food.

On the other hand the IE comparisons are flawed. Lithuanian šérti, šeriù etc. cannot be related to Lat. cenena, kŕma, and *(s)ker-; with its initial *k', however, it may be related to Albanian thier, thjerr(ë) 'ervum lens', which I have analyzed $(B u$ letin Shkencor, Seria e shkencave shoqërore /Univ. Luigj Gurakuqi/ 27 /47/ 1/1994, 89-90). Russ. Ukr. Br. korm, OPol. karm and Slovak krm $<* k r m b$ are not directly the expected *kor-mó-s, which is functionally equivalent to Lat. cēna. Here *krms must be contaminated with *krmá the well formed IE ancestor of krma I, SCr. kŕma, Bulg. kbrmá, Mak. krma, ${ }^{1}$ Ukr. korma, and Slovak krma.

\footnotetext{
${ }^{1}$ Mak. krna appears to be a misprint.
} 
We recover here in krma $I$ an interesting addition to the examples I have adduced in $K Z$ 96, 1982/83, 171-7.

kŕma II 'puppis' (Bezlaj 96) is accorded an account, with references to earlier literature. But despite the rich citation of Slovene derivatives no explication of the morphology is actually supplied; Etimologija ni razčiščena. At least this morphology is discussed by this writer in KZ 96, 171-7, esp. 171 and 176.

The toponym Krma III is referred to pre-Roman origins - often a counsel of despair - with the mention of Albanian karmë 'cliff, wall'. I have, however, derived karmë from *karp-nă an old collective. The Lautgesetz involved here is purely Albanian, and imposes thereby a severe constraint on the presumed source.

We have here, then, three different formations. The lexeme krma II could have an origin in the base *krp-; cf. Latin corpus, Baltistica 15, 2 (1979) 145 (OPruss. kerrmens), and Études Celtiques 9 (1960) 139-40 (139, Welsh cryf <*kr(p)mo-).

\section{2 kášelj}

The Slovene evidence on this interesting etymon is very important, and the account of F. Bezlaj ESSJ II (1982) 22-3 does not bring this out sufficiently. It is of course correct that the Proto-Slavic form must be reconstructed $* k \bar{a} \breve{s} l j o$ - vel sim, as Bezlaj does. However the cited Church Slavonic kašılb shows a written internal jer. It is therefore important to note the Slovene 18th century attestations which include kashl. Of course the question of precise (morpho)phonemic status enters here, as well as that of the phonetics of 16th century kashel. But the native testimony is itself a valuable datum.

The Indo-European account, and the setting within the IE dialects, for this item is deficient. For a fuller accounting see E. P. Hamp, in Ezikovedski proučvanija v čest na Akad. V. I. Georgiev, Sofia: BAN, 1980, 130-4; Indo-Iranian Journal 30, 1987, 103-6; Ériu 39, 1988, 193-4; Scottish Gaelic Studies 16, 1990, 194.

\section{3 ógenj}

As with kášelj the Slovene testimony for ógenj is rich and important (ESSJ II, 1982 , 243). We note especially the 17 th century oghgn, a highly valuable form to be placed alongside the Church Slavonic ogńb.

However the Indo-European account which follows the recital of Slavic cognates is not at all acceptable, and the appeal to linguistic tabu is simply a confession of failure to find any principled solution. On the whole question I would refer the interested reader to my discussion and analysis in T. F. Magner and W. R. Schmalstieg eds., Baltic Linguistics, University Park: Pennsylvania State University Press, 1970, 75-9. On the exact background of vígenj 'forge, hearth' I have now (Rocznik stawistyczny 49, 1, 13-14) revised my view and formulation as follows: Cz. výhen̆, $\mathrm{SCr}$ vìganj, Slov. vígenj < *výgnjb < (by Winter's lengthening) *ugnio- < (by dissimilation or perceptual misassignment) *ungnio- $<* n g n i-o-$.

The question of vatra has no part in this discussion, and I have dealt with that etymon elsewhere, esp. Opuscula slavica et linguistica: Festschrift für Alexander Issatchenko, Klagenfurt 1976, 201-10; Revue roumaine de linguistique 26, 1981, 315. 


\section{4 ọglje}

As with the last item, the Slovene testimony for ôglje is highly valuable and rich in its variety and citation of variants (ibid. 243-4). The 18th century form ogl is particularly interesting, and the range of attested suffixation is instructive. But again the comparative Indo-European account is deficient.

My 1970 essay mentioned under ógenj deals also with ôglje and kindred forms, and the reader is again referred to that. The etymon of ogel 'angulus' is also mentioned there, but that is not part of the main focus there. However that discussion does deal with the Albanian loan from Slavic for which Bezlaj simply cites and reproduces Pisani's uninformed confusion.

Prispelo maja 1995

Eric P. Hamp

Received May 1995

University of Chicago

Uredništvo je na sestanku 6. decembra 1996 odločilo, da se ob soglasju avtorja in recenzentke objavi tudi recenzija tega prispevka.
At the meeting of the Editorial Board on December 6, 1996, it was decided that with the agreement of the author and the reviewer, the review would be published accompanying the article. 